James Gardner

\title{
Even Orpheus Needs a Synthi
}

Since his return to active service a few years ago ${ }^{1}$, Peter Zinovieff has appeared quite frequently in interviews in the mainstream press and online outlets ${ }^{2}$ talking not only about his recent sonic art projects but also about the work he did in the 1960s and 70s at his own pioneering computer electronic music studio in Putney. And no such interview would be complete without referring to EMS, the synthesiser company he co-founded in 1969, or namechecking the many rock celebrities who used its products, such as the VCS3 and Synthi AKS synthesisers.

Before this Indian summer (he is now 82) there had been a gap of some 30 years in his compositional activity since the demise of his studio. I say 'compositional' activity, but in the 60s and 70s he saw himself as more animateur than composer and it is perhaps in that capacity that his unique contribution to British electronic music during those two decades is best understood. In this article I will discuss just some of the work that was done at Zinovieff's studio during its relatively brief existence and consider two recent contributions to the documentation and contextualization of that work: Tom Hall's chapter ${ }^{3}$ on Harrison Birtwistle's electronic music collaborations with Zinovieff; and the double CD Electronic Calendar: The EMS Tapes, ${ }^{4}$ which presents a substantial sampling of the studio's output between 1966 and 1979. Electronic Calendar, a handsome package to be sure, consists of two CDs and a lavishly-illustrated booklet with lengthy texts. The first CD is divided into two sections: 'Peter Zinovieff \& Harrison Birtwistle', and 'Peter Zinovieff \& Hans Werner Henze'. The second CD is credited to 'Peter Zinovieff \& Friends', though most of the tracks on it are Zinovieff's alone.

It would be easy to caricature Electronic Music Studios (London) Ltd. as A Very British Adventure - a kind of Carry On Synthesising. The absence of financial acumen; the saucy adverts; the whiff of faded aristocracy; the cast of colourful characters; the long boozy lunches; the tilting at technological windmills; the vaguely bohemian atmosphere; the sleeves-rolled, low-budget ingenuity masking genuine innovation; the words 'Putney' and 'Cricklewood'5 - and the inevitable, ignominious demise - all conform to the trope. It's also tempting to swallow the

\footnotetext{
${ }^{1}$ The two main triggers leading to Zinovieff's creative re-emergence were his appearance in Mathew Bate and Claire Harris' short film on EMS, What The Future Sounded Like (Porthmeor Productions, 2006) <http://www.whatthefuturesoundedlike.com> The commission, instigated by Russell Haswell, of the piece Bridges from Somewhere and Another to Somewhere Else was part of The Morning Line project for TBA21, and exhibited in Istanbul in 2010.

${ }^{2}$ See, for example, Zinovieff's 2010 appearance at the Red Bull Academy, http://www.redbullmusicacademy.com/lectures/dr-peter-zinovieff-the-original-tectonic-sounds ${ }^{3}$ Tom Hall, 'Before The Mask: Birtwistle's electronic music collaborations with Peter Zinovieff' in Beard, Gloag and Jones (eds.) Harrison Birtwistle Studies (Cambridge: Cambridge University Press, 2015), pp. 63-94.

${ }^{4}$ Peter Zinovieff, Electronic Calendar: The EMS Tapes (Space Age Recordings ORBIT015CD, June 2015).

5 'The Putney' was the alternative name for the Mk I VCS3; 'The Cricklewood' was the name of EMS's first musical keyboard.
} 
prevailing cartoon "computer boffin" image of Zinovieff as the company's "mad professor" main man, quixotically grappling with recalcitrant machinery in his "shed" studio, cajoling colleagues to make breakthroughs by dint of his forceful personality, and consorting with a coterie of 70s pop stars. ${ }^{6}$

There's more than a bud of truth in those burlesques, of course. Former associates of Zinovieff's during the 1970s attest to his powers of persuasion, to his emanation of a Jobs-like reality distortion field; the equipment was unreliable and labour-intensive and it is true that notable rock musicians did indeed travel to Putney to twiddle on EMS synthesisers. And yes, he did have a studio at the bottom of the garden.

For most of its existence, EMS had two streams of activity that were essentially separate: Zinovieff's electronic music studio, based in his house and dedicated almost exclusively to "serious" music, including work with Birtwistle, Henze and others; and the synthesiser company. Zinovieff saw the manufacture and sale of EMS synthesisers purely as a means to an end - that end being the financing and development of his studio, for many years the only computer-based one in the country, and one which required constant injections of capital to upgrade and develop its hardware and software.

The tale of EMS's synthesiser business, which effectively began around November 1968 with the building of the Don Banks Music Box ${ }^{7}$, is a complex, colourful and fascinating one. For the last couple of years I've been researching this story and hope to recount it at length (along with an account of the studio) in a future publication. But EMS synthesisers, attractive as they are, have almost nothing to do with any of the Birtwistle-Zinovieff collaborations discussed by Tom Hall, nor any of the music on Electronic Calendar. With two exceptions ${ }^{8}$, this was all produced at Zinovieff's Putney studio, utilising its unique equipment.

One might despair at the current tendency of music journalists to overlook such simple fact-checking, thus perpetuating easily-debunked myths; and their rush to heap acclaim on the electronic music 'pioneer' $d u$ jour - seemingly anyone who noodled on a synth before 1990. On the other hand, there is also much serious investigative work being undertaken on figures connected with British electronic music. For example, in Leeds, James Mooney has his ongoing Hugh Davies Project ${ }^{9}$, in Sydney, Nicole Saintilan is studying Don Banks' electronic

\footnotetext{
${ }^{6}$ A typical recent example of gullible coverage would be Ben Beaumont-Thomas, 'Peter Zinovieff: "I taught Ringo to play synth. He wasn't very good - but neither was I"' The Guardian, 20 October 2015. http://www.theguardian.com/music/2015/oct/20/peter-zinovieff-ringo-ems-synthsinterview

7 This device became known later as the VCS-1, and its commission by Banks led to the invention, by Zinovieff, David Cockerell and Tristram Cary, of the VCS3, launched in November 1969.

${ }^{8}$ The exceptions are Zinovieff's Electronic Calendar track 'Now Is The Time To Say Goodbye', and Birtwistle's incidental music for Ibsen's Brand, which Hall briefly discusses. Both involved Zinovieff's studio in Great Milton, Oxford, whither he moved in late 1976. A detailed account of Birtwistle's music for the National Theatre is eagerly awaited.

${ }^{9}$ See <https://hughdaviesproject.wordpress.com>
} 
music ${ }^{10}$, while Mathew Adkins and others have forensically examined Roberto Gerhard's work in the genre. And - operating outside the academic enclave independent researcher Ian Helliwell's tenacious and enterprising work on a host of lesser-known figures in the asteroid belt of British electronic music should not be overlooked ${ }^{11}$.

Despite this, there are still gaping holes in the history: balanced, well-researched non-hagiographic books on the work of Delia Derbyshire ${ }^{12}$ and Daphne Oram have yet to appear, while a serious and comprehensive account of Tristram Cary's life and work is way overdue. One waits impatiently, too, for the contribution to British live electronic music made in the late 60s and early $70 \mathrm{~s}$ by Tim Souster, and his group Intermodulation - co-founded with the late Roger Smalley - to be properly acknowledged and chronicled.

It is disappointing, then - but perhaps inevitable - that reviews of Electronic Calendar have routinely invoked the kneejerk namedropping of Eno, Kraftwerk, Pink Floyd and Stockhausen. ${ }^{13}$ Those noteworthy bands and individuals did indeed use EMS synthesisers at one time or another, but there are two names that are of much greater pertinence to any discussion of Zinovieff's studio and the work done there: David Cockerell and Peter Grogono.

Cockerell was Zinovieff's principal design engineer from his arrival in September 1966 until his final departure from the company in November 1974, and most of Zinovieff's specialised hardware was Cockerell's handiwork. ${ }^{14}$ Grogono, meanwhile, developed the music program MUSYS between 1969 and 1973. This allowed composers to control, via computer, the various sound-producing and processing devices in Zinovieff's studio. ${ }^{15} \mathrm{Few}$ of the pieces on Electronic Calendar, or those discussed by Hall, would be the same without Cockerell or Grogono's work, and it is not too much of a stretch to claim that the collaboration between Zinovieff and Cockerell is what is really being celebrated here.

Zinovieff had a basic studio up and running at his Ebury Street house by the beginning of 1963 but he doesn't seem to have completed any pieces there. It wasn't until he moved to Putney towards the end of 1965 that he took his hobby more seriously, as evidenced by his commissioning of a purpose-built structure

\footnotetext{
10 Banks was, of course, Australian but he started his electronic work in the London and was associated with the British electronic art music scene in the early 1970s.

11 Helliwell's book on this subject, Tape Leaders is currently in preparation.

12 At present, perhaps Louis Niebur's judicious and well-contextualized outline of Derbyshire's work in his Special Sound: The Creation and Legacy of the BBC Radiophonic Workshop (Oxford: Oxford University Press, 2010) comes closest, but a dispassionate, even-handed and thorough account of her life and work is, alas, unlikely to appear in print for some time yet.

13 Tom Hall is alert to this journalistic tendency: see his article 'Peter Zinovieff and Cultures of Electronic Music', Page (69): Bulletin of the Computer Arts Society, Spring 2013.

14 Cockerell also played a crucial role in the design of most of EMS's signature products, e.g. the VCS3 and Synthi 100 synthesisers, its sequencers, and the Synthi Hi-Fli.

15 Zinovieff had, in fact, been using his computer to control sound devices from its arrival in his studio in mid-1967, thanks to various interfacing devices developed with Cockerell. MUSYS was, however, easier to use and more powerful than the programs Zinovieff had used until that point.
} 
for the studio in the garden. ${ }^{16}$ By 1966 he had set up an informal electronic music production team, Unit Delta Plus, with Brian Hodgson and Delia Derbyshire, both moonlighting from the BBC Radiophonic Workshop. The trio sporadically worked on joint projects through 1966 and 1967, including perhaps the first public concert of electronic music in Britain ${ }^{17}$.

Two of Zinovieff's earliest extant pieces, Tarantella and Agnus Dei, were played at this concert and each represents one of Zinovieff's longstanding compositional preoccupations. Tarantella is a short study with a more-or-less constant pulse and a narrow timbral range, but the specific pitches heard at any given moment were chosen by a purpose-built 'sequencer' relying on probability-weighted randomness ${ }^{18}$, and the loudness was set randomly between two limits. This emphasis on weighted randomness and probability (i.e. a kind of algorithmic approach to composition) was something that Zinovieff doggedly pursued thereafter - he hated splicing tape to produce sequences of sounds. And the limitations of the sequencing equipment at his disposal in 1966 led him to buy a computer the following year for its potential to be the 'ultimate sequencer'.

Agnus Dei, on the other hand, reflects Zinovieff's interest in concrète sounds, which he found - and continues to find - a much richer source of material than sounds generated from scratch electronically. Much of the piece was composed from the electronically-processed singing voice of Josceline Gaskell ${ }^{19}$ with a few sequenced electronic sounds. An excerpt from this piece was released on $\mathrm{CD}^{20}$ in 2000, on the same label as Electronic Calendar, Spage Age Recordings. It would be reasonable to assume then, that the track labeled Agnus Dei on Electronic Calendar would either be this previously-released excerpt, or perhaps a different selection. But no. And here we encounter two of the most serious failings of the CD set. First, there's virtually no information about any of the tracks that are included, and second, there's a frequent mismatch between the track names and what's actually on the CD. What is purportedly Agnus Dei appears to be a track that, while using some of the same 1966 source material, has additional spoken and whispered lines from the $8^{\text {th }}$ century text 'The Ruin', and is probably the backing track made to accompany a live recital by Laurie Lee of a Zinovieff poem at one of the EMS-sponsored concerts at the Queen Elizabeth Hall21.

As far as the paucity of relevant documentation about the tracks on Electronic Calendar is concerned, Zinovieff comes off very slightly better than the other represented composers - at least a few of his hard-to-find texts from the late 1960 s are reproduced. In this way we are able to read at least a few of the

\footnotetext{
16 This structure, often referred to as a "shed" was designed and built by Nicholas Dimbleby.

17 At the Watermill Theatre, Bagnor, Newbury on 10 September 1966.

18 The source of randomness in this case was the radioactivity from colleague Mark Dowson's luminous radium-dial wristwatch, picked up by a Geiger-Müller tube. The resulting pulses were used to interrupt a ring-counter to supply random data.

19 Now better known as the writer Josceline Dimbleby.

20 Various artists: Interface (Space Age Recordings ORBIT 019CD, 2000).

21 On 24 April 1972, a concert that also included the premiere of Birtwistle's Chronometer.
} 
composer's words about January Tensions ${ }^{22}$, only an excerpt from which is included on the CD.

Although the inclusion of Zinovieff's texts is welcome, the Electronic Calendar booklet fails to credit their provenance. In fact, 'A Computerised Electronic Music Studio in London' was first published in the DECUS proceedings ${ }^{23}$ and later, in an updated form, in 'Electronic Music Reports'. ${ }^{24}$ Zinovieff's 'The Special Case of Computer Intuitive Music Scores' first appeared in the programme booklet of a 1969 EMS/Redcliffe concert ${ }^{25}$, and later in The London Magazine. ${ }^{26}$ And so on. It is, of course, unreasonable to expect Space Age Recordings' booklet to masquerade as an academic paper, with fussy footnotes and references, but at least some acknowledgement of sources would make the package much more useful and dispel the impression that the documentation has been carelessly cobbled together.

No author is credited for the five discursive essays included in the CD's documentation, although presumably it is Peter Kember, the man behind the Electronic Calendar project. These essays do provide a valuable sketch of Zinovieff, EMS and the workings of the studio, but it is a pity that the author whoever s/he, or they, may be - lets their obvious and genuine enthusiasm for the project, and their Zinovieff zealotry, bubble into a text that is high on hyperbole and littered both with literals and simple errors of fact.

It would be tedious and unnecessary to catalogue all of these, so I will give just one example. The booklet states: 'The computer first entered this story in 1965 when Mark Dowson, suggested it might better serve [Zinovieff's] needs than the large analogue sequencers built by Cockerell to control the banks of oscillators, amplifiers and filters.' This single sentence is wrong on a number of counts. It is true that Dowson proposed the use of a computer to satisfy Zinovieff's growing demands on the sequencers. But it was also Dowson who, in September 1966, introduced Zinovieff to Cockerell. Cockerell then succeeded Dowson. Cockerell had not worked for Zinovieff until that point, and had not, therefore, built him any 'large analogue sequencers'. These were built by Dowson with Humphrey Evans $^{27}$, or by Zinovieff himself.

\footnotetext{
22 Not, as the booklet implies, part of the Unit Delta Plus concert; it was realised in 1968 and premiered at the London Planetarium on 22 March.

23 Peter Zinovieff, 'A Computer Controlled Electronic Music Studio', DECUS Proceedings 1968 (Fourth European Seminar), Maynard, Mass. pp. 139-145.

24 Peter Zinovieff, 'A Computerized Electronic Music Studio', Electronic Music Reports, No.1 (September 1969), Institute of Sonology at Utrecht State University, pp. 5-22.

25 This was a foil-covered booklet produced for a QEH concert on 10 February 1969 which included Birtwistle's Four Interludes for a Tragedy. The booklet is significant for its inclusion of advertisements for the first commercially available EMS products and a lengthy discussion of Zinovieff's studio.

${ }^{26}$ Peter Zinovieff, 'The Special Case of Computer Intuitive Music Scores' London Magazine Vol. 9, No.4, (July 1969), pp. 165-176

${ }^{27}$ Evans worked very sporadically for Zinovieff between summer 1966 and January 1969.
} 
Furthermore, Zinovieff took delivery of his DEC PDP-8/S computer - famously financed by the sale of his wife's tiara - in mid-1967, not in 1965. To the casual reader these may seem like petty details, but if the aim is - as it would appear to establish Zinovieff's credentials as a pioneer, and to document the evolution of the studio, it is crucial to get this stuff right.

The photographs in Electronic Calendar, many of which are published here for the first time, are certainly impressive yet they have neither credits nor captions ${ }^{28}$. There are many ogling close-ups of studio equipment but we are left to guess at what they actually show, how it fits into the story, or what it has to do with sounds we hear on the CDs. Electronic Calendar does deserve some credit for allowing us to hear some of the music produced in the studio during this period, much of which has been more read about than heard. But the lack of documentation actually does the music on it - and Zinovieff - a terrible disservice.

This is particularly true in the case of, say, A Lollipop for Papa, which to many listeners might sound like a grotesque parody of Switched-On Bach: a series of synthesised variations on the third movement of Haydn's keyboard sonata Hob. $\mathrm{XVI} / 34$ that gradually get further away tonally and rhythmically from the original. Lightweight on the surface, perhaps, but it helps to know that the piece was generated in September 1969 to demonstrate the flexibility and potential power of Grogono's MUSYS 3 as a music programming language, and that it was recorded in real time with no overdubs. Only then can one start to appreciate the piece's significance. Given this dearth of documentation it is difficult to understand why minuscule offcuts of Zinovieff's work, merely labelled 'Un Known' or 'Un Named', are included in this collection at all. ${ }^{29}$

Zinovieff attributes much of the success in his working relationship with the composers Harrison Birtwistle and Hans Werner Henze to the fact that neither took part directly in the technical realization of their electronic works - they were very much 'hands off' in this regard. Henze corroborates this in his memoirs, recalling that he was usually immediately satisfied by whatever Zinovieff was doing, so he 'did not have to stay too long surrounded by all this meaningless and unloved software.'30

Sadly, Electronic Calendar contains no documentation whatever for the Zinovieff/Henze works on its first CD so we are left to deduce that, for instance, the track 'Tristan (short section)' is the second part of the 'Epilogue' from Henze's Tristan, completed in 1973 and released in its entirety on a Deutsche Grammophon $\mathrm{LP}^{31}$. Astute listeners might divine that the track features not only the endearing voice of Zinovieff's second son Kolinka (family connections loom large in the Zinovieff/EMS story) but also the heartbeat of one of the Zinovieffs'

\footnotetext{
28 The sole exception is the photo of the 1970 MUSYS system at EMS, reproduced - with its original Letraset labelling - on pp. 22-23 of the booklet.

${ }^{29}$ A longer offcut, 'June Rose' seems to be just a source tape for Henze's China Music.

${ }^{30}$ Hans Werner Henze, Bohemian Fifths: an autobiography (Princeton, N.J., Princeton University Press, 1999), p. 318.

${ }^{31}$ Hans Werner Henze, Tristan (Deutsche Grammophon 2530 834, 1977)
} 
grey whippets, laid over the music from the prelude to Act III of Wagner's Tristan und Isolde.

Meanwhile, the track credited as 'Tristan (long section)' isn't from Tristan at all. It is actually an excerpt from the electronic/tape part of the third movement of Henze's Second Violin Concerto, the full recording of which was originally released in 1974 as part of Decca's fondly-remembered 'Headline' series ${ }^{32}$. Again, Electronic Calendar provides no creation date for the excerpt but, in the unlikely event that a listener felt mysteriously compelled to glance at the preface to Henze's score while listening to the track, they would quickly discover that Zinovieff realized the electronic music at EMS between $17^{\text {th }}$ and $24^{\text {th }}$ June 1972 .

As a researcher it is interesting to hear this selection without the solo violin and orchestral music that accompanies it in Henze's concerto. It gives a vivid impression of the typically gritty electronic sound produced by the studio at that time, mains hum and all. But for the lay listener the excerpt, with its spoken text from Enzenberger's Hommage à Gödel, is more likely to be heard as a puzzling torso. One might argue that the lack of track information on Electronic Calendar allows listeners to hear the pieces just as they are, without any claims being made on their behalf. That is true, but for what is essentially an archival and historical release it is frustratingly unhelpful. On the second 'Zinovieff \& Friends CD, Justin Connolly's 1968 piece M-Piriform (now withdrawn) appears not in its full form, with live soprano, flute and violin ${ }^{33}$, but as an excerpt from the electronic/pre-recorded component only. No singer is credited, but the soprano is unmistakeably Jane Manning. Yet even this decontextualized chunk is disfigured by digital dropouts ${ }^{34}$.

Zinovieff first encountered the Hebridean island of Raasay while working on his DPhil in geology in the 1950s and established a strong connection with the place that endures to this day. He lived there in the 1980s and during the EMS years of the 60s and 70s holidayed there frequently, often with EMS employees; these trips have since become part of the company's folklore. In 1975 Birtwistle bought a cottage on the island from Zinovieff and lived and worked there for about eight years, producing what I feel are some of his most memorable and significant pieces ${ }^{35}$. Birtwistle's Raasay years are covered intelligently and in some depth by Nicholas Jones in his chapter ${ }^{36}$ in Harrison Birtwistle Studies.

\footnotetext{
32 Hans Werner Henze, Compases para preguntas ensimismadas/Violin Concerto No. 2 (Decca HEAD 5, 1974).

33 A full performance of this piece may be seen towards the end of the BBC-TV programme on electronic music, Same Trade As Mozart, first broadcast on 3 August 1969.

34 At 6'10", 6'15" and 6'40".

35 These include Silbury Air, Carmen Arcadiae Mechanicae Perpetuum, much of The Mask of Orpheus, and the Clarinet Quintet.

36 Nicholas Jones, 'The sound of Raasay: Birtwistle's Hebridean experience' in Beard, Gloag and Jones (eds.) Harrison Birtwistle Studies (Cambridge: Cambridge University Press, 2015), pp. 175205.
} 
The track 'Raasay Digitised'37, included on Electronic Calendar, features the computer-manipulated voice of Zinovieff's fellow islander Roddy Macleod, recounting 'a tale about Murdo the blacksmith cocking a snoop at the rent collector in the $1840 \mathrm{~s}^{\prime}{ }^{38}$ In this track, Macleod's voice is not 'sampled' in the current sense of the word - Zinovieff's computers lacked both the speed and storage capacity for that. Rather, Cockerell's filter bank - the heart of the EMS studio - acted more like a 64-channel vocoder, allowing a source sound to be analysed and a reasonable simulacrum of it to be resynthesized, using a data stream small enough for the PDP-8 to handle. An additional advantage was that the analysed sound could be manipulated within the computer before being resynthesised, thus allowing sonic transformations that were impossible using standard tape-manipulation or voltage-control techniques.

Transmitting recognizable speech with much-reduced data was one of the goals of telecommunications in the early 70s, as it still is now, and the potential of this vocoding technique for such a purpose meant that 'Raasay Digitised' was probably used as a VOCOM demo. The tale of EMS's ill-fated flirtation with high finance and American investors over VOCOM - an impossibly ambitious datacompression project for international telephony - is far too convoluted to be recounted here, but suffice it to say that for much of 1973 this white elephant diverted the energies of Zinovieff, Cary, Cockerell and other EMS personnel from the company's core business, and - thanks to a fraudulent cheque - pierced a hole in EMS's finances from which, arguably, it never recovered.

The extent of Harrison Birtwistle's dalliance with the electroacoustic medium may come as a surprise to those familiar only with his instrumental or vocal music. Yet his interest in the field went back at least as far as the early 60s. David Beard, writing elsewhere in Harrison Birtwistle Studies, quotes Birtwistle's December 1965 application for a Harkness Fellowship to Princeton: 'my particular interests would be analysis and electronic techniques'. ${ }^{39}$ When Birtwistle returned from a stint in the States, he was searching for a collaborator in the electronic field, and he eventually found one in the shape of Zinovieff. Tom Hall writes that 'the details and significance of Birtwistle's collaborations with Zinovieff to date have not been sufficiently documented.' 40 This is certainly true, and his well-researched chapter goes a long way to increase that documentation. It is also an extremely valuable addition to the body of serious literature on British electronic music of the '60s and '70s.

When Birtwistle began his own engagement with electronic music there were few studios in Britain at all. Tristram Cary had his well-equipped and idiosyncratic studio in Fressingfield, but that was mostly used for his own projects. Rudimentary studios at Goldsmiths College and the Royal College of

\footnotetext{
37 This title is a modern re-naming - the contemporary term used by EMS for 'digitised' would be 'analysed'. The piece's alternative title is 'Rent Collection Day'.

38 Peter Zinovieff, personal communication 6 September 2015.

39 David Beard, 'The life of my music': what the sketches tell us', in Beard, Gloag and Jones (eds.) Harrison Birtwistle Studies (Cambridge: Cambridge University Press, 2015), pp. 120-174, at 147n.91.

40 Hall (2015), p. 63.
} 
Music were only just being set up, and while freelance composers Roberto Gerhard and Humphrey Searle had occasionally used the BBC Radiophonic Workshop for non-BBC projects, it was primarily a service department for BBC productions, closed to outsiders. Zinovieff's studio, in contrast, was open to any composer he thought capable of producing aesthetically interesting or technically challenging work. By the time Birtwistle started working with Zinovieff, the studio had already built up a relationship with visiting composers in preparation for an SPNM composers' weekend in July $1968^{41}$ at which Justin Connolly and David Lumsdaine produced pieces under Zinovieff's supervision.

Given the lack of viable alternatives, it is therefore hardly surprising that Birtwistle ended up working with Zinovieff, but Hobson's choice does not account for the strong working relationship and personal rapport that the two men rapidly established, nor for the friendships that grew between their similarly-aged children. As I mentioned earlier, some of the success of Birtwistle and Zinovieff's collaboration sprang from a clear division of labour, with Birtwistle never touching the studio equipment, but the two men also shared an interest in 'random numbers and how to tame them' 42 for musical ends. They were also united by their aversion to the typical angular, pointillistic jump-cut style of much electronic music of the time, preferring to create electronic "auras".

In his chapter, Tom Hall reveals the unsuspected extent of Birtwistle's commitment to, and advocacy for, electronic music in Britain at this period. For a while at least he was the chairman of the British Society for Electronic Music, ${ }^{43}$ and in this capacity he wrote a letter to Benjamin Britten requesting support for Zinovieff's tenacious but ultimately unsuccessful bid for his studio to become the National Studio. ${ }^{44}$ Hall also includes a useful overview of all of the BirtwistleZinovieff collaborations - both electronic and verbal ${ }^{45}$ - and it is useful to have these disparate works collected in one place. Many of the works with electronics are relatively minor Birtwistle pieces, and most have been withdrawn, but as part of the larger picture they are still worth studying.

Hall rightly reserves much of his space for a highly detailed and thoughtful examination of Chronometer (1971-72), the most substantial of Birtwistle and Zinovieff's electronic collaborations, and the real meat of Hall's chapter. ${ }^{46}$ The source sounds for this piece were dozens of recordings of clocks, watches and other timepieces, which were, like Roddy Mcleod's voice, "analysed" then modified, re-ordered and resynthesized into an impressive horological

\footnotetext{
41 Anthony Gilbert, 'SPNM Composers' Weekend', The Musical Times, Vol. 109, No. 1508, p. 946.

42 Peter Zinovieff, interview with the author, 26 November 2014.

43 Zinovieff was secretary, or at least honorary secretary, of the BSEM.

${ }^{44}$ Zinovieff's efforts in this direction are discussed in Nicola Candlish's 2012 PhD thesis 'The Development of Resources for Electronic Music in the UK, with Particular Reference to the bids to establish a National Studio', Durham theses, Durham University http://etheses.dur.ac.uk/3915/.

45 Zinovieff wrote the libretto and scenario for Birtwistle's opera The Mask of Orpheus and the words for Nenia, the Death of Orpheus for soprano and ensemble.

46 Hall intriguingly reveals that one of Birtwistle's initial ideas for the piece was to do with weaving looms and shuttles, but curiously does not remark on Stockhausen's use of the shuttle sound as a formal marker in his Trans (1971).
} 
processional. The technically significant point here was that, as Zinovieff remarked, 'all subsequent manoeuvres were made by computer regeneration rather than by tape-montage techniques. ${ }^{\prime 4}$

Electronic Calendar's inclusion of a version of Chronometer - confusingly dubbed Chronometer '71 - is very welcome. This version first appeared as side two of an Argo LP in 1975, aptly coupled with Birtwistle's orchestral piece The Triumph of Time. But as far as I am aware, this is its first release in digital form. A fourchannel (and stereo) version of Chronometer was released in $2008^{48}$, but this was sourced from a different master tape ${ }^{49}$, and Hall draws our attention to the many obvious - and not-so-obvious - differences between the two versions, offering further evidence of his very close listening.

He cannily examines the pitch content of the piece, too - a parameter all too easily overlooked in an ostensibly "concrete" work. To what extent Birtwistle consciously structured the pitch content is unclear, but the presence of clear pitches within the dense collage may also be attributed to a technical limitation of Cockerell's filter bank. Its 64 filters were usually tuned in semitones, covering a pitch range from $\mathrm{C} 2$ to $\mathrm{E} 7$, and it was through this low-resolution chromatic grid that the incoming sounds were passed, "analysed" and resynthesized. As I have already suggested, this device lent its distinctive shimmering and grainy sonic signature not only to Chronometer but to much of the studio's output from October 1971 onwards.

While the EMS studio was, at its height, quite advanced in some respects, it lagged in others, most notably the recording and mixing chain. Chronometer, as Hall correctly observes, was produced using two asynchronous 4-track Ampex tape machines at a time when 16-track was standard - and 24-track emerging in professional recording studios in London. And compared to the complex, timbrally sophisticated computer music that John Chowning and Jean-Claude Risset were creating at Bell Labs around this time, the products of Putney were rough-hewn and unpolished: more Béton brut than filigree silver, and yet, in its 'truth to materials', perhaps better suited to Birtwistle's aesthetic.

Chronometer was premiered at the QEH in April 1972, in the third of the four more-or-less annual Redcliffe concerts of electronic music that Cary and Zinovieff organised. These concerts functioned as something of a shop window for EMS, each showcasing to a large audience a number of pieces that had been realised at the Putney studio. The first of these concerts, given to a packed QEH on January 151968 included Zinovieff's Partita for Unattended Computer, the

\footnotetext{
47 Peter Zinovieff, booklet notes for Chronometer, (Argo ZRG 790), dated 1974.

48 Various Composers, Recovery/Discovery: 40 years of Surround Electronic Music in the UK (Sound and Music SAM 081, 2008).

${ }^{49}$ As Hall points out, the four-track master tape used for the SAM release is believed to have been the one played at the piece's premiere. It therefore pre-dates the source of Chronometer '71, which is a copy of the master prepared for the 1975 vinyl release, and may or may not also be the 'revised version' advertised for a QEH performance in April 1973.
} 
first live computer 'recital' in the UK, again using probabilistic computergenerated sequences but rather rudimentary sounds. ${ }^{50}$

Birtwistle and Zinovieff's first collaboration, Four Interludes for a Tragedy for basset clarinet and tape, was premiered at the second of these QEH concerts in February 1969. On Electronic Calendar we are presented with what is presumably the source tape of Zinovieff's electronic contribution, without Alan Hacker's basset clarinet. Apart from that obvious absence, this version differs substantially from the previously available recording 51 of the piece, for which two of the four electronic sections presented here were used as the sources for the four interludes ${ }^{52}$. Hacker, writing in the liner notes for the clarinet and tape $\mathrm{CD}$, explained that 'We chose backing tracks for the Interludes like wallpaper and later when recording them for an LP, one of them had to be abandoned, because a backing-track frequency made the needle jump grooves on the vinyl. ${ }^{53}$

Clearly the story is more complicated than that, but again no documentation is provided on Electronic Calendar to give us any more clues. From a scholar's point of view this karaoke version is useful, as one can focus on the rather mournful and brooding synthesized "auras" as they pursue their own single-minded trajectories. But the price one pays is the loss of the emotive lines of the basset clarinet reflecting on the unnamed tragedy. The nameable tragedy, though, is that the track is marred by another of the audio glitches plaguing this release: at the end of the Interludes, we are suddenly confronted with the first thirty seconds or so of Henze's Glass Music before it starts again in its proper place as the next track. Even then, the piece's mesmerizing Baschet-like sonorities are interrupted by what sounds like a dodgy splicing-in of leader tape around the three-minute mark.

Having become familiar with Birthday Song from a lo-fi source of dubious origin, I was looking forward to hearing a clean copy of Birtwistle and Zinovieff's lighthearted $70^{\text {th }}$ birthday tribute to Alfred Schlee. ${ }^{54}$ Alas, this piece has fallen prey to yet another Electronic Calendar mastering malfunction. Instead of this track perhaps the earliest extant demonstration of Cockerell's filter bank/vocoder we merely get the first 80 seconds of Chronometer '71 again. Yet none of the reviews of Electronic Calendar that I have read so far has mentioned any of these all-too-audible problems. Reviewers seem both ill-equipped to describe and evaluate what they are hearing and also unable to place this music into any kind of post-war art music context, or even a technical one. Instead, they seem content

\footnotetext{
${ }^{50}$ Archive footage from this event, with Cary introducing the item and Zinovieff and an assistant starting the computer appears in What The Future Sounded Like, at 14'32".

${ }^{51}$ Released on LP as L'Oiseau-Lyre DSL017 in 1977 and reissued on CD by Clarinet Classics in 2006.

52 To be specific: the electronic part of Interlude 1 on Hacker's recording is an edit of Interlude 2 on Electronic Calendar; Hacker's Interlude 2 is a double-speed version of $E C$ Interlude 1; AH Interlude 3 is an edit of the normal speed $E C$ Interlude 1, and AH Interlude 4 is a different edit of $E C$ Interlude 2. Consequently, the third and fourth interludes on Electronic Calendar appear for the first time on record.

53 Alan Hacker, liner notes to A Portrait of Alan Hacker (Clarinet Classics CC052, 2006)

54 The director of Universal Edition, then Birtwistle's publisher.
} 
to paraphrase the frothy, hyperbolic and inaccurate spin from the Space Age Recordings press release ${ }^{55}$, or parrot such inanities as 'These could easily be the themes or background music for an intelligent, minimal, dystopian sciencefiction film.'56

In Hall's discussion of the smaller-scale Birtwistle pieces, he claims that 'Little is known'57 about the second version of Birtwistle's Linoi. Gentle digging, however, unearths facts: the premiere took place on 22 April 1969 at the Queen Elizabeth Hall, and contemporary reviews give us some clues to its nature:

'Linoi 2, [...] has a dancer (Clover Roope) unfolding and swooping about while a tape recorder gives distorted comments on Linoi I for clarinet and (un-keyboard) piano. The two levels of happening were more intriguing than the piece as an entity-though it is a pleasure just to hear Birtwistle's imagination at work, it is so musical. ${ }^{58}$

'[Linoi I's] successor is an expanded version for basset clarinet, piano and tape, which the programme note described as "the generation, the simultaneous flowering and destruction, and the prolonged death agony of a single melodic line." A good description, for the work had all the implied sense of growth and decline and was all in all rather touching. 59

Hall is also puzzlingly vague on another subsequently-withdrawn piece, Signals, for basset clarinet and tape. He relies only on a score excerpt from Robert Adlington's book ${ }^{60}$, and Michael Hall's description, ${ }^{61}$ which states that Alan Hacker gave the première of Signals in August 1970 in Edinburgh. Yet at least three more performances took place the following year and, again, one can glean at least something about the piece from contemporary accounts ${ }^{62}$. Reporting on its London premiere at QEH on 18 January, Ronald Crichton detailed the differences between this performance and the Edinburgh premiere:

'Different, not only because the signals received by the clarinettist from a tape and effecting his choice of five sets of possible answers arranged in a semicircle before him recur in random order, but because the tape was controlled not by the clarinettist but by an assistant (Michael Nyman in the shadows at the back), also because the constant drone that forms a background to the dialogue was supplied by nine squatting players of big bamboo pipes'. 63

\footnotetext{
55 See <http://www.adasamshop.com/index.php/record-labels/space-age/peter-zinovieff.html> 56 Stuart Benjamin, review of Electronic Calendar for the 'Echoes and Dust' website, 11 July 2015. < http://echoesanddust.com/2015/06/peter-zinovieff-electronic-calendar-the-ems-tapes/> 
From the last comment one might at least infer, then, that the drone was originally on tape. Hacker and accomplices performed the 'big bamboo' version again at a concert with the Gabrieli Quartet on 1 March $1971^{64}$, and a variant for six clarinets was given by Hacker's RAM students at the QEH on 23 May $1972^{65}$.

Hall asserts that Birtwistle's final "instrument plus tape" piece, Chanson de Geste 'has not been heard in public since its première in Perugia by Fernando Grillo'. 66 This is not strictly accurate. True, there do not seem to have been any further performances of the double bass and tape version after its debut in July 1973, but the following month Alan Hacker gave a basset-horn rendition of the piece in Edinburgh. The Guardian critic wrote: '[I]t is a relaxed study in slow moving melody, a testimonial to the self-control of the composer, the clarinettist [...] and, of course, the pre-recorded tape.' 67

As for the content of that tape, the score's preface merely states that:

'The pre-recorded continuo consists of two basically contrasting elements.

1. A continuous element.

2. An intermittent, more percussive element.'68

[A diagram is then given mapping out their temporal sequence.]

'The performed music also consists of two elements. 1. The CANTUS, a continuous unbroken line. 2. 6 PUNCTI, intejectory [sic] complexes from which the performer derives part of the material.'

Given Birtwistle's preoccupation with 'cantus' and 'continuum' in subsequent works, Adlington ${ }^{69}$ rightly draws links from Chanson de Geste to Secret Theatre, but the former's preface also makes clear that - as so often in Birtwistle's music a spatial element is an integral part of the composition: '[E]ach of the 4 speakers [...] must be placed round the audience in four quadrants, and as far away from them as possible'. None of this gives us much of an idea of what the specific sounds on the four-track tape were, but one would hope that at some point it might be possible, perhaps with help from the BBC, for a well-produced archival release of recordings of such material.

Chanson de Geste was also presented in the last of the previously-mentioned EMS/Redcliffe QEH concerts on 26 November 1973, an occasion that also included the premiere of Henze's China Music. For this concert the solo instrument in Chanson de Geste was replaced by a group of five in a realisation by Christopher Wintle. Paul Griffiths wrote: 'The aching lines were typical of Birtwistle, but the work might well be more effective-particularly in its

\footnotetext{
64 Gerald Larner, 'Gabrieli Quartet at Harewood House', The Guardian, 2 March 1971, p. 8.

65 Stephen Walsh, 'Respectably Modern', The Times 24 May 1972, p. 15.

66 Hall (2015), p. 72.

67 Gerald Larner, 'Giulini and the LSO at the Usher Hall', The Guardian, 24 August 1973, p. 12.

68 Harrison Birtwistle, Chanson de Geste, (London: Universal Edition, 1973) UE 15561; the underlining and capitalisation is taken from the original.

${ }^{69}$ Adlington (2000) p. 57.
} 
handling of the tape-live discourse-in the solo form. ${ }^{70}$ Wintle himself recalls that:

'For an upcoming concert at the Queen Elizabeth Hall [...] I had invited HB to write a new piece (it wasn't exactly a "commission"). He agreed. As the day of the concert approached, no piece had emerged. Frantic communications through a third party to the US, where HB was stationed at the time, led to an instruction to find a tape accompanying a double-bass solo, Chanson de Geste, and turn it into a quintet. This I did, elaborating the raw material into a web of little canons. ${ }^{71}$

The Mask of Orpheus occupied a vast amount of Birtwistle and Zinovieff's time and energy between the early 70s and the mid-80s. As Hall points out, this 'arguably had detrimental consequences for the EMS business' 72 and both families' lives were caught up with the project during their sojourns on Raasay. Here, and at Putney, Zinovieff's eldest daughter Sofka produced many poster and set designs for the opera. Some of these were used in the booklet of the NMC $\mathrm{CD}^{73}$, and one was appropriated for an EMS synthesiser advert : 'Even Orpheus Needs a Synthi' [see fig. X]. Such re-purposing was not without precedent: in 1971, Birtwistle's Medusa score (slightly modified!) had been similarly pressed into service to advertise EMS's then-new Synthi range. [see fig. Y]

Despite the close and lengthy collaboration between composer and librettist on The Mask of Orpheus, the obvious and long-planned employment of Zinovieff's studio for the opera's electronic music did not eventuate. Hall usefully discusses the extensive plans for the involvement of EMS in the opera in some detail and with hindsight it is sad to know that Zinovieff's high hopes for this aspect of the project would - perhaps inevitably - be dashed. In a letter to Don Banks, written from Raasay in 1975, Zinovieff says, rather optimistically:

'The real stuff begins this October with the electronics for Orpheus. There is a great deal of varied music. It ranges from unaccompanied electronic pieces (6 at about 3 minutes each) to voice transformations, which will be pre-recorded.

There is also a large amount of live electronics. I suppose that there is at least a year's full time studio work on this opera. It will test all the resources of the studio and the programmes. ${ }^{74}$

By this time, however, EMS was starting to flounder. The fallout from the VOCOM debacle and the failure of new EMS products to capture the changing synthesizer market, soon to be dominated by cheap, reliable and musician-friendly Japanese instruments, led the company into a terminal decline. David Cockerell had left, sundering the crucial creative relationship that he and Zinovieff enjoyed, and the

\footnotetext{
70 Paul Griffiths: 'Birtwistle, Harvey', The Musical Times Vol. 115, No. 1571 (Jan., 1974), p. 57.

71 Christopher Wintle, personal communication, 5 August 2015. A studio recording of this arrangement, performed by the Ulysses Ensemble and conducted by Jonathan Harvey, was broadcast by the BBC on 23 April 1974.

72 Hall (2015), p. 87.

73 Harrison Birtwistle, The Mask of Orpheus (NMC D050, 1997)

${ }^{74}$ Letter from Peter Zinovieff to Don Banks 25 July 1975, Powerhouse Museum, Sydney: Qasar /Tony Furse archive, Correspondence 96/382/2-3.
} 
cash-strapped EMS studio was being left in the dust by better-funded and more technically advanced facilities such as IRCAM, which became the obvious choice for the realization of the electronic parts of Birtwistle's opera after Zinovieff's studio closed in $1979^{75}$.

In its time, the EMS studio produced relatively few complete works, partly due to Zinovieff's unflagging drive to expand and upgrade the equipment. This led to a constantly changing studio that was at the limit of what Cockerell and his colleagues could keep working reliably, and was in contrast, say, to Tristram Cary's technologically simpler studio in Fressingfield, where the pragmatic composer produced work to order under tight deadlines. It had little or none of the R\&D aspect that in many ways prevented Zinovieff's studio from being a reliably functioning production facility.

Tom Hall's chapter is a fine contribution to the history of this extraordinary place, and it may be that the few puzzling shortcomings in his text that I have pointed out, plus its light sprinkling of typos, are the products of editorial oversights. Electronic Calendar, however, is at best a stopgap, a missed opportunity. We still await a fully-documented set of remastered recordings from the EMS studio that would locate its strengths and weaknesses in a balanced historical, technical and sociocultural context.

75 EMS - the synthesiser company - changed hands a number of times after its initial collapse in December 1979, and was eventually bought in 1995 by Robin Wood, who first joined EMS in 1970. As EMS (Cornwall) Ltd., he keeps the flame (and the archive), and still builds VCS3 and Synthi A synthesisers by hand to special order. 